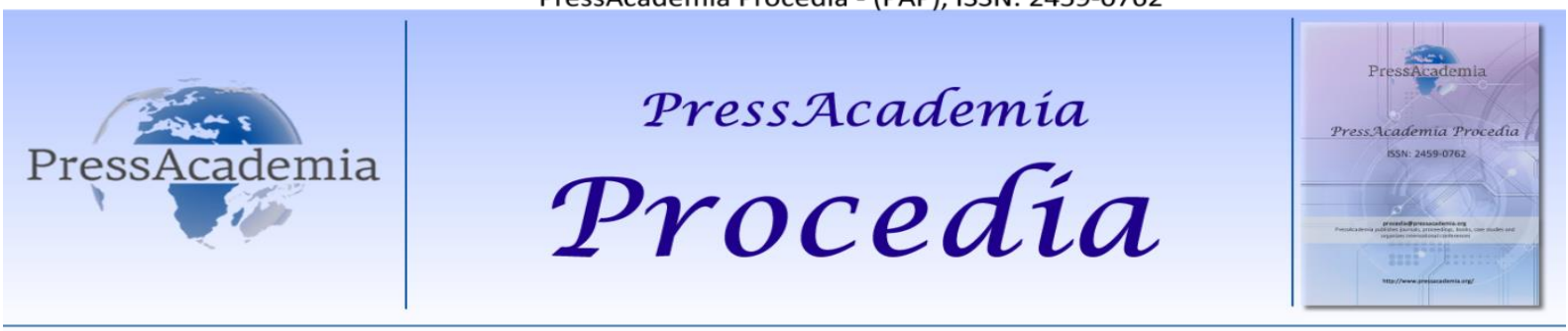

Global Business Research Congress (GBRC), May 24-25, 2017, Istanbul, Turkey

\title{
REVIEW OF SUBSCALE OF THE ORGANIZATIONAL SILENCE ETHICAL CLIMATE AND MANAGEMENT STYLE IN PUBLIC INSTITUTIONS: AN EXAMPLE IN ERZURUM HEALTH SECTOR
}

\author{
DOI: 10.17261/Pressacademia.2017.651 \\ PAP- GBRC-V.3-2017(77)-p.737-745 \\ Salih Bortecine Avci ${ }^{1}$, Omer Siddik Budak ${ }^{2}$ \\ ${ }^{1}$ Atatürk University, iiBF, Erzurum, Türkiye. savci@atauni.edu.tr \\ ${ }^{2}$ Kafkas University, Sarıkamış Vocational School, Kars, Türkiye. omerbudak@kafkas.edu.tr
}

\section{To cite this document}

Avci, S. B. and O. S. Budak (2017). Review of subscale of the organizational silence ethical climate and management style in public institutions: an example in Erzurum health sector. PressAcademia Procedia (PAP), V.3, p.737-745.

Permemant link to this document: http://doi.org/10.17261/Pressacademia.2017.651

Copyright: Published by PressAcademia and limited licenced re-use rights only.

\begin{abstract}
Nowadays, one of the concepts, that have an impact on many factors such as staff commitment and motivation in public institutions, is the subject of organizational silence. Organizational climate and management methods of executives rank among on the basis of many factors causing organizational silence. This investigation compared the relationship between management styles, ethical climate and organizational silence. In the application part, data were collected by 5 point likert questionnaire from a public hospital located in the center of Erzurum province with its 2500 Employees. We conducted correlation analyse to determine whether an effect between management styles, ethical climate and organizational silence. It is possible to say that the employees of the institution will remain silent to keep the harmony and friendship environment to continue if given the opportunity to create a family atmosphere and show their creativity. In the event that the authoritarian management approach is effective within the organization, the result is that employees can remain silent because of the fear of encountering negative consequences and increasing workload. Findings support previous research showing that organizational slience is related to management styles and ethical climate. If the management makes an effort to provide team spirit and business cooperation within the organization, Employees may not declare their ideas so that this environment does not deteriorate. If the management team evaluates employees in terms of pressure, discipline and obedience; Employees can be silenced by fear, ingenuity and cunning.
\end{abstract}

Keywords: Organizational Slience, Management Styles, Ethical Climate, Health, Human Resource Management

JEL Codes: L10, L25, M10

\section{KAMU KURUMLARINDA ÖRGÜTSEL SESSIZLIK, ETIK İKLIM VE YÖNETIM TARZLARI ALT BOYUTLARININ INCELEMESI: ERZURUM SAĞLIK SEKTÖRÜNDE ÖRNEK BİR UYGULAMA}

\section{ÖZET}

Günümüzde kamu kurumlarında personel taahhüdü ve motivasyon gibi bir çok faktörü etkileyen kavramlardan biri de örgütsel sessizlik konusudur. Örgütsel iklim ve yönetim tarzı, örgütsel sessizliğe etki eden birçok faktörden sadece bazılarıdır. Bu araştırmada, yönetim tarzları, etik iklim ve örgütsel sessizlik arasındaki ilişki karşılaştırılmışır. Uygulama bölümünde, Erzurum il merkezinde bulunan bir kamu hastanesinde çalışan 2500 kişi ile anket çalışması yapılmış ve $5^{\prime} \mid$ li likert şeklinde sorulmuş sorularulardan oluşan anket formu ile veriler toplanmıştır. Yönetim tarzları, etik iklim ve örgütsel sessizlik arasında bir etkinin olup olmadığını belirlemek için korelasyon analizi yapılmıştır. Bulgulara göre; kurum çalışanlarının kurum içerisinde aile ortamının oluşturulması ve yaratııııklarını göstermeleri için fırsat verilmesi durumunda sessiz kalacaklarını söylemek mümkündür. Kurum içerisinde otoriter yönetim anlayışının etkin olması durumunda çalışanların negatif sonuçlarla karşılaşma ve iş yükünün artması gibi korkulardan dolayı sessiz kalabilecekleri bulgusu elde edilmiştir. Bulgular, örgütsel sessizliğin yönetim tarzları ve etik iklim ile ilişkili olduğunu gösteren daha önceki araştırmaları desteklemektedir. Yönetimin örgüt içerisinde takım ruhunu ve iş birliğini sağlayabilmek için çaba sarf etmesi durumunda; çalş̧anlar bu ortamın bozulmaması için fikirlerini beyan etmeyebilirler. Eğer yönetim kademesi çalışanları baskı, disiplin ve itaat çerçevesinde değerlendirirse çalışanlar korku, yöneticilere yaranma ve kurnazlık duygusuyla sessizliğe bürünebilirler.

Anahtar Kelimeler: Örgütsel Sessizlik, Yönetim Biçimleri, Etik İklim, Sağlık, İnsan Kaynakları Yönetimi JEL Kodları: L10, L25, M10 


\section{GíRiş}

Son yıllarda sağlık örgütlerinde hem bireysel hem de yapısal değerledirmelerde, örgütsel sessizlik ve etik iklim konuları ile ilgili çalışmaların sayısında artış yaşanmaktadır. Çalışanlar bazen çoğunluğun sesine uyduklarını göstermek için veya diğer görüşleri onayladıkları için susma yolunu seçmektedirler (Dyne, Ang, ve Botero, 2003). Bazen de konuşacakları zaman kendilerinin veya diğer örgüt üyelerinin zarar göreceklerini bildikleri için ya da ellerindeki fırsatları kaçırmamak için susmaktadırlar (Brinsfield, 2009; Knoll ve Dick, 2013). Buna neden olan faktörlere bakıldığında ise karşımıza örgütsel faktörler çıkmaktadır. Özellikle yöneticilerin yönetim tarzları ve örgüt içerisinde oluşturulan etik iklimin rolü çok büyüktür.

Başarılı bir yönetim için yönetim tarzlarını doğru seçmeleri gereken örgütler, farklı birçok değişkeni göz önünde bulundurarak yönetim tarzlarını belirlerler. Çalışanların performansları açısından düşünülecek olursa başarının yakalanabilmesi için en uygun yönetim tarzının belirlenmesi gerekir (Örs, 2010). Ancak bu yönetim tarzları oluşturulurken çalışanlar üzerindeki etkilerinin değerlendirilmediği durumlarda negatif etkiler ortaya çıkabilmektedir. Çalışanların istekli ve arzulu bir şekilde yönetime dahil olması ve yaratıcı fikirlerini örgüte kazandırmalarını sağlayan yönetim tarzları, örgüt açısından oldukça faydalı olmaktadır. Öte yandan çalışanları kutuplaştıracak, dışlayacak ve safdışı edecek yönetim tarzları ise çalışanların karamsar bir havaya girmelerine ve içe kapanık bir hale bürünmelerine neden olabilir.

Yönetim tarzının yanında örgütsel iklim açısından etik iklimin oluşturulmamasının da çalışan üzerinde negatif etkileri bulunmaktadır. Örgüt içerisinde var olan uygulama ve faaliyetlerin davranışsal yönü olarak etik iklim (Cullen ve diğ., 2003) örgütte var olan süreç içerisinde ortaya çıkan durumlarda yapılması ve yapılmaması gereken işlerin yorumlandığı bir süreçtir (Parboteeah ve diğ., 2005). Örgüt elemanlarının var olan sorunları çözmek için çaba göstermeleri şarttır. Bu konuda gerek yönetim gerekse de çalışan sınıfın yol haritası olan etik bir iklim (Barnett ve Schubert; 2002) oluşturulmadığında doğru davranışın ne olduğu hakkında çalışanların kafaların karışması muhtemeldir.

Bu çalışmada sağlık kurumlarında oluşturulan yönetim tarzları ve etik iklimin örgütsel sessizlikle nasıl bir ilişkiye sahip olduğunun tespit edilmesi amaçlanmıştır. Mevcut çalışma kapsamında Erzurum ilinde faaliyet gösteren bir sağlık kuruluşu mercek altına alınmıştır. Bu kapsamda öncelikle literatür değerlendirilmesi yapılmış ardından 296 katılımcının cevapladığı anketlerin bulguları değerlendirilmiştir.

\section{LITERATÜR INCELEMESI}

\section{1. Örgütsel Sessizlik}

Örgütsel sessizlik, örgüt elemanlarının bilerek görüş, teklif, öneri ve sıkıntıları aleni bir şekilde dile getirmemesi, kendi içine kapanması şeklinde açıklanmaktadır (Erenler, 2010; Pinder ve Harlos, 2001). Literatürde var olan örgütsel sessizlik tanımları ışığında bir tanım yapılacak olursa; örgüt üyelerinin çeşitli baskı ve tepkilere maruz kalması, var olan fikirlerin üst yönetim tarafından önemsenmemesi, önemli bilgilerin kendilerinde kalma isteği, var olan düşünceye onay verilmesi, kendilerini ifade edememe ve grup üyeleri arasında sivrilip dışlanma gibi nedenlerden dolayı var olan işle ilgili görüş ve fikirlerini ortaya koymamaları durumu örgütsel sessizliği oluşturur. Knoll ve Dick (2013) örgütsel sessizliğin alt boyutlarını şu şekilde belirlemiştir. Buna göre "Kabul Edilmiş Sessizlik", "Örgüt Yararına Sessizlik", "Pasif Sessizlik" ve "Fırsatçı Sessizlik" örgütsel sessizliğin alt boyutlarıdır.

\subsubsection{Kabul Edilmiş Sessizlik}

Kabul edilmiş sessizlik, örgüt elemanlarının örgüt içerisinde var olan olumlu-olumsuz durum ve şartları kabullenip bu şartlara herhangi bir itiraz etmeden sessiz kalmalarıdır (Dyne ve diğ., 2003). Kabul edilen sessizlik konusu örgüt çalışanlarının itaatkâr olması ile ilişkilidir (Şehitoğlu, 2010). Bir örgüt içerisinde var olan itaatkâr çalışanlar, kendileri için söz konusu olan durumu her şartta kabul edebilmektedirler. Yanık’a (2012) göre; kabul edilen sessizlik ortamını etkileyen etmenlerden birisi toplum kültürüdür. "Güç mesafesi" kültürü, örgüt içerisinde kabul edilen sessizlik ortamının oluşabilmesi için etkileyici bir etmen olarak görev alır. Örgüt üyeleri, örgüt içerisinde hiyerarşik anlamda kendilerinden daha yukarda bulunan yönetici sınıfının her zaman en iyisini bildiklerini düşünürler. Çakıcı'ya (2010) göre; öğrenilmiş çaresizlik ile kabul edilen sessizlik ortamı arasında da bir ilişki söz konusudur. Öğrenilmiş çaresizlik sonucu çalışanlar kendi görüşlerinin ilgili merciler tarafından ciddiye alınmadığını hissedebilirler. Aynı zamanda kendilerini sürekli işe yaramayan taraf olarak hissetmeleri söz konusudur. 


\subsection{2. Örgüt Yararına Sessizlik}

Örgüt yararına sessizlik, çalışanların örgütün zarar görme ihtimaline karşı var olan olumlu-olumsuz şartlar ile ilgili fikir beyan etmesi yerine fikirlerini söylemeyerek sessiz kalması olarak açıklanmaktadır (Dyne ve diğ., 2003). Örgüt yararına sessizliğin örgütsel vatandaşlık değişkeni ile ilişkili olduğu söylenebilir (Özgen ve Süregevil, 2009). Örgüt içerisindeki diğer üyelere çeşitli eylemlerde yardım edilmesi ve onların düşünülmesi üzerine inşa edilen örgütsel vatandaşılı örgüt yararına sessizliğide akabinde getirecektir (Özdevecioğlu, 2003).

\subsubsection{Pasif Sessizlik}

Pasif sessizlik, Pinder ve Harlos'un 2001'de sessizlik boyutu olarak ortaya çıkardığı bir sessizlik türü olarak karşımıza çıkıyor (Kahya, 2015). Pasif sessizlikle savunmacı sessizlik arasında ince farklar vardır. Pasif sessizlikte itaat ve korku duygularından kaynaklı bir sessizlik vardır. Kişi kendini biraz daha arka planda tutmaya çalışır. Pasif sessizlikte; kişi, kendini düşündüğünden negatif düşüncelerini söylememe gereği duyar. Pasif sessizlik ile savunmacı sessizlik arasındaki ince ayrımı net olarak ortaya koyacak olursak; Savunmacı sessizlikte sessizliğin temel nedeni korku iken, pasif sessizlikte çalışan desteklemediği bazı durumlar için alternatif çözüm önerilerinin farkında olmasına rağmen strateji gereği konuşmaz (Knoll ve Dick, 2013).

\subsubsection{Fırsatçı Sessizlik}

Fırsatçı sessizlik, Knoll ve Dick'in örgütsel sessizliğe kattıkları dördüncü boyuttur. Knoll ve Dick'e (2013) göre; fırsatçı sessizlik, kişilerin kurnazlık temelli çıkarlarına yönelmesi durumudur. Karacaoğlu ve Küçükköylü (2015), fırsatçı sessizliği tanımlarken çalışanların kendi yararlarını düşünmeleri sonucu sessiz kalmalarından bahsetmişlerdir. Bu sessizlik türünde kişiler önceden yaptıkları planlar doğrultusunda menfaatçi duygularla olaya yaklaşarak önceden yaptıkları planlar doğrultusunda hareket ederler. Bu kişiler için susmak, menfaat getiriyorsa en rasyonel karardır. Bu sessizlik türünde, çalışanlar örgüt içerisinde avantaj sağlayabilmek için elde ettikleri bilgileri saklayabilirler. Sapkınca bir sessizlik türü olarakda algılanabilir. Örgüt elemanı, başkalarının zararının olup olmadığını umursamadan kendi yararı söz konusu ise sessiz kalmayı tercih eder.

\subsection{Yönetim Tarzları}

Örs'e (2010) göre; yönetim anlayışının yöneticilerin kişilikleri, inandıkları değerler, yaşam tarzları, çalışanlara karşı duyulan güven gibi birçok değişkene göre değişmesine yönetim tarzı denir. Örgütlerin yönetim tarzlarının farklılık göstermesinin en önemli nedeni farklı kültürel yapılara sahip olmalarıdır (Örs, 2010). Bu yönetim tarzları otoriter yönetim tarzı, demokratik yönetim tarzı, serbestlik tanıyan yönetim tarzı ve paternalist yönetim tarzıdır.

Otoriter yönetim, yönetim kademesinde çalışan yöneticilerin diğer çalışanlardan etkin ve verimli bir performan beklemesi ve bu performansı elde edebilmek için gerekirse çalışanları cezalandırmaya varana kadar giden yönetim tarzıdır (Örs, 2010). Demokratik yönetim, çoğunluğun söz sahibi olduğu katılımcı bir yönetim anlayışıdır. Bu yönetim anlayışında alınan kararlarda tüm örgüt üyelerinin fikrinin alınması ve tüm çalışanların yönetime dahil edilmesi söz konusudur (Örs, 2010). Serbestlik tanıyan yönetim tarzında ise, yönetim kademesinin çalışanlara müdahalesinin nerdeyse sıfıra indiği ve örgüt içerisinde çalışanların kendi haline bırakıldığı yönetim tarzıdır. Bu yönetim tarzında yönetim kademesinin gereksiz olduğu görüşü hakimdir. Yönetim kademesinin etkisi olmadanda çalışanların doğru karar verebileceği düşünülmektedir (Cengiz, 2010). Paternalist yönetim, yöneten sınıf ile çalışan sınıf arasındaki ilişkinin baba-oğul ilişkisi şeklinde olması gerektiğini söylemektedir (Fişek, 2011).

\subsection{Etik iklim}

Etik iklimin literatürde ahlaki iklim veya etik atmosfer olarak ta karşımıza çıktığını görmekteyiz (Büte, 2011). Araştırmacılar, 1900'lü yılların başlarından itibaren örgüt içerisinde etkin ve verimliliği artırmak amacıyla insan davranışlarını incelemeye başlamış ve söz konusu sosyal faktörler oldukça fazla ilgi çekmiştir. Bu bağlamda araştırmacıların inceledikleri terimlerden biriside etik iklimdir. Araştırmacılar çeşitli yollar belirleyerek çalşanların etik iklim atmosferine girmelerini amaçlamışlardır. Dolayısıyla yıllar geçtikçe araştırmacılar "etik iklim" kavramını sıklıka gündeme getirmişlerdir (Bilgen, 2014). Sağnak (2005) örgütsel anlamda etik iklimin tanımı üzerinde düşünerek şöyle bir tanım yapmıştır; örgüt çalışanlarının örgüt kültürünü ahlaki anlamda oluşturarak dış çevreye göstermeleridir. Eğer bir örgütte etik iklim etkili değilse etik dışı davranışlar fazlasıyla olabilmektedir. Örgüt içerisindeki olumsuzların en büyük nedeni, etik dışı bir havanın olmasıdır. Bu durumda çalışanlar, sorunlu ve uzlaşmaz bir tavır sergileyebilmektedirler. Örgütün tamamı açısından düşünecek olursak; irtikap, rüşvet, zimmete geçirme, sahtekarlık, liyakatsizlik, kayırmaca gibi olumsuz davranışlar ortaya çıkabilmektedir (Gül, 2006). Bu 
olumsuz davranışların ortaya çıkmaması için etik anlamda faaliyetlerin geçekleşmesi gerekir. Bu anlamda yöneticilerin etik çerçevede kararlar vermesi, çalışanların ise etik davranışlardan ödün vermemeleri gerekmektedir (Sonakın, 2010).

\section{VERI VE YÖNTEM}

\subsection{Araştırmanın Amacı ve Varsayımları}

Araştırmamızın amacı örgüt içerisindeki yönetim tarzı, etik iklim ve örgütsel sessizlik değişkenlerinin alt boyutları arasındaki karşılıklı ilişkiyi belirlemektir. Örgüt başarısını olumlu etkileyecek değişkenlerin ortaya çıkarılıp bu yönde teşviklerin sağlanması ve olumsuz etki yaratan değişkenler konusunda önerilerde bulunulması gerekir. Bu araştırmada örgütteki yönetim kademelerinin tasarrufları ve yönetim anlayışlarının örgütsel sessizlikle pozitif bir ilişkiye sahip olduğu varsayılmaktadır. Bunun yanı sıra çalışanların örgüt içerisinde ki etik iklime göre sessiz kalma durumlarının değişkenlik gösterebileceği varsayılmaktadır.

\subsection{Araştırmanın Evreni ve Örneklemi}

Araştırmamızın evrenini Erzurum ilinde bulunan bir kamu hastanesinde kadrolu, sözleşmeli ve şirket personeli olarak çalışan görevliler oluşturmaktadır. Hastanenin özlük işleri departmanından hastanede toplam çalışan personel sayısının toplamda 2500 olduğu öğrenilmiştir.

Örneklemi belirlerken hastanelerin yoğun çalışma tempoları göz önünde bulundurularak basit tesadüfi örnekleme yöntemi kullanılmıştır. Basit tesadüfi örnekleme yöntemi ile hastanede çalışan kişiler tesadüfi olarak seçilmiş ve anket uygulamasına dâhil edilmiştir. Örneklem sayımız 0.05 örnekleme hatasına göre 333 olarak belirlenmiştir. Hastanede 335 anket formu dağıtılmasına rağmen 296 tane anket formu geriye döndüğü için bu 296 anket formuyla analizler yapılmıştır.

Tablo 1: Demoğrafik Veriler

\begin{tabular}{|r|c|c|r|c|c|}
\hline \multicolumn{1}{|c|}{ Cinsiyet } & $\mathbf{N}$ & $\mathbf{\%}$ & Yaş & $\mathbf{N}$ & $\mathbf{\%}$ \\
\hline Bay & 147 & 49,7 & $18-25$ & 38 & 12,8 \\
\hline Bayan & 149 & 50,3 & $26-30$ & 67 & 22,6 \\
\hline Toplam & 296 & 100 & $31-35$ & 110 & 37,2 \\
\hline Görev Süresi & & & $36-45$ & 64 & 21,6 \\
\hline $1-5$ yıl & 81 & 27,4 & 46 ve üzeri & 17 & 5,7 \\
\hline $6-10$ yıl & 95 & 32,1 & Toplam & 296 & 100 \\
\hline $11-15$ yıl & 68 & 23 & Meslek & & \\
\hline 16 ve üzeri & 52 & 17,6 & Doktor & 30 & 10,1 \\
\hline Toplam & 296 & 100 & Hemşire & 129 & 43,6 \\
\hline Çalışılan Birim & & & Memur & 30 & 10,1 \\
\hline Acil & 25 & 8,4 & VHKi & 42 & 14,2 \\
\hline Poliklinik & 57 & 19,3 & Teknisyen veya Tekniker & 21 & 7,1 \\
\hline Servis & 144 & 48,6 & Diğer & 44 & 14,9 \\
\hline Teknik & 3 & 1 & Toplam & 296 & 100 \\
\hline İdari & 67 & 22,7 & & & \\
\hline Toplam & 296 & 100 & & & \\
\hline
\end{tabular}

\subsection{Araştırma Modeli}

Araştırma modelimizde yönetim tarzları, etik iklim, örgütsel sessizlik boyut ve alt boyutlarının karşılıklı ilişkileri yer almaktadır. 
Şekil 1: Araştırma Modeli

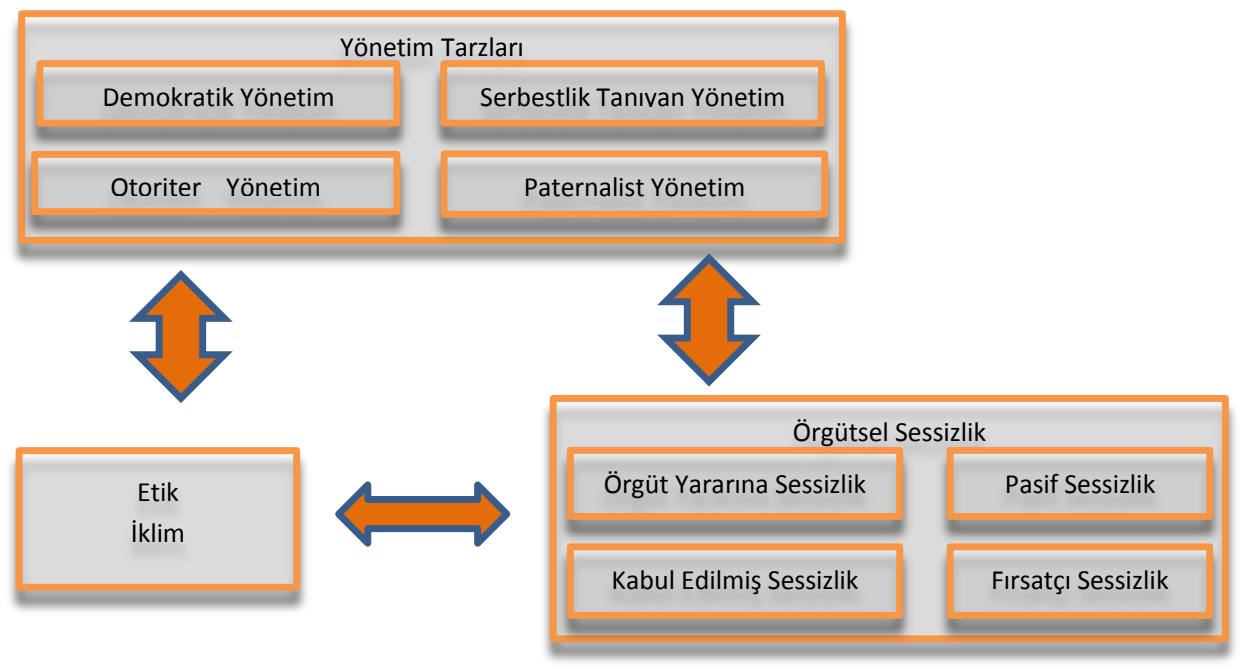

\subsection{Veri Toplama Yöntemi ve Ölçek Geliştirme}

Araştırma için gerekli olan veriler "Sağlık Sektöründe Yönetim Tarzı, Etik İklim ve Örgütsel Sessizlik Anketi" isimli anket ile toplanmıştır. Anket maddeleri oluşturulurken yerli ve yabancı literatürden yararlanılıp uzman hocalarımızın görüşleri alınmış ve Atatürk Üniversitesi Sosyal ve Beşeri Bilimler Etik Kurulunun onayı alınmıştır. Anketimizin birinci bölümünde cinsiyet, yaş, görev süresi, meslek grubu, kadro türü ve çalışılan birimin sorulduğu demografik sorular yer almaktadır. Anketimizin ikinci bölümünde ise; örgütsel sessizlik ölçeği, Michael Knoll ve Rolf van Dick'in 2013 yllında Pinder ve Harlos (2001) ile Dyne ve diğerleri (2003) tarafından işlenen boyutlara istinaden hazırladıkları dört boyutlu örgütsel sessizlik anket sorularının uzman görüşleri ışığında revize edilmesi ile oluşturulmuştur. Ölçek güvenilirliği Cronbach's Alpha yöntemiyle hesaplanmış ve yüksek güvenilirliğe sahip olduğu anlaşılmıştır. Bu ölçek için faktör analizi yapıldığında 14 maddenin faktörlere dağıldığı görülmüştür. Maddelerin faktör dağılımları Tablo 3.2'deki gibidir. Örgütsel Sessizlik ölçeği için yapılan faktör analizinde KMO oranı, 0,899 ve anlamlılık düzeyi 0,00 olarak bulunmuştur. Maddelerin 4 faktör altında toplandığı gözlemlenmiştir. Bu faktörler kabullenici sessizlik, pasif sessizlik, örgüt yararına sessizlik ve fırsatçı sessizliktir. Bu 4 alt boyut Örgütsel Sessizlik ölçeğini \% 70,60'ını açıklamaktadır.

Tablo 2: Örgütsel Sessizlik Ölçeği Açıklayıcı Faktör Analizi Sonuçları

\begin{tabular}{llllll}
\hline Maddeler & Kabullenici & Pasif & Örgüt Yararına & Fırsatçı & $\begin{array}{l}\text { Cronbach' } \\
\text { s }\end{array}$ \\
& Sessizlik & Sessizlik & Sessizlik & Sessizlik & Alpha \\
\hline ks2 & 0,818 & & \\
ks3 & 0,802 & & 0.851 \\
ks4 & 0,746 & & \\
ks1 & 0,676 & & \\
\hline ps2 & & & & \\
\hline
\end{tabular}




\begin{tabular}{llll} 
ps1 & 0,628 & & 0.758 \\
ps3 & 0,619 & & \\
\hline öys4 & 0,704 & 0.781 \\
öys2 & 0,667 & \\
öys3 & 0,609 & & \\
öys1 & 0,508 & & \\
\hline fs1 & & 0,770 & \\
fs2 & & 0,733 & 0.704 \\
fs3 & & 0,726 &
\end{tabular}

Etik iklim ölçeği, Charles H. Schwepker, ve David J. Good'ın 2009 yılında kullandıkları anket formunun uzman görüşleri ışığında revize edilmesi ve kendi toplum kültürümüze uyarlanması ile hazırlanan 4 sorudan oluşan tek boyutluk bir formdur. Bu ölçeğin güvenilirliği Cronbach's Alpha $(\alpha=0.778)$ yöntemiyle hesaplanmış yüksek güvenilirliğe sahip olduğu anlaşılmıştır. Yönetim tarzı ölçeği, Pellegrini ve Scandura'nın 2008 yılındaki çalışmaları, Bektaş’ın 2014 yılındaki çalışması ve Batmaz'ın 2012 yılında yaptığı çalışmalarda kullandıkları anket sorularının uzman görüşleri ışığında revize edilmesi ve kendi toplum kültürümüze uyarlanması ile hazırlanan dört boyutlu bir formdur. Bu ölçeğin güvenilirliği Cronbach's Alpha yöntemiyle hesaplanmış ve yüksek güvenilirliğe sahip olduğu anlaşılmıştır. Yönetim Tarzları ölçeğindeki maddeler için faktör analizi yapıldığında 17 maddenin faktörlere dağıldığı görülmüştür. Maddelerin faktör dağılımları Tablo 3.3.'daki gibidir. Yönetim Tarzı ölçeği için yapılan faktör analizinde KMO oranı, 0,852 ve anlamlılık düzeyi 0,00 olarak bulunmuştur. Maddelerin 4 faktör altında toplandığı gözlemlenmiştir. Bu faktörler demokratik yönetim, otoriter yönetim, serbestlik tanıyan yönetim ve paternalist yönetimdir. Bu 4 alt boyut yönetim tarzı ölçeğini \% 74,215'ini açıklamaktadır.

Tablo 3: Yönetim Tarzı Ölçeği Açıklayıcı Faktör Analizi Sonuçları

\begin{tabular}{|c|c|c|c|c|c|}
\hline & Demokratik & Otoriter & Serbestlik Tanıyan & Paternalist & Cronbach's \\
\hline Maddeler & Yönetim & Yönetim & Yönetim & Yönetim & Alpha \\
\hline dy2 & 0,828 & & & & \\
\hline dy3 & 0,825 & & & & \\
\hline dy4 & 0,792 & & & & 0.885 \\
\hline dy5 & 0,786 & & & & \\
\hline dy1 & 0,665 & & & & \\
\hline oy5 & & 0,882 & & & \\
\hline oy4 & & 0,843 & & & \\
\hline oy2 & & 0,800 & & & 0.887 \\
\hline oy3 & & 0,718 & & & \\
\hline
\end{tabular}




\begin{tabular}{llll}
\hline sty3 & 0,890 & & \\
sty2 & 0,887 & & \\
sty1 & 0,814 & & \\
sty4 & 0,704 & & \\
\hline py2 & & 0,786 & \\
py3 & & 0,708 & 0.877 \\
py1 & & 0,686 & \\
\hline
\end{tabular}

\section{BULGULAR VE TARTIŞMA}

Yapılan korelasyon analizi ile yönetim tarzı, etik iklim ve örgütsel sessizliğin alt boyutları arasındaki ilişki ortaya konulmak istenmiştir. $p=0,01$ ve $p=0,05$ düzeyinde anlamlı ilişkiler görülmüştür. Sadece kabullenici sessizlik ve paternalist yönetim arasında anlamlı bir ilişkinin olmadığı görülmektedir. Tablo 4'e $r$ değerlerine baktığımızda hastanede etkin olan demokratik ve paternalist yönetim tarzlarının ilişkilerinin en yüksek olduğu sessizlik alt boyutu olan örgüt yararına sessizlik faktörüdür. Otoriter yönetim tarzının en yüksek anlamlı ilişkisi ise fırsatçı sessizlik faktörüyledir. Yine etik iklimin ilişkisinin en yüksek olduğu sessizlik alt boyutları örgüt yararına sessizlik ve pasif sessizliktir. Etik iklimin yönetim tarzları alt boyutları ile ilişkisine baktığımız zaman en yüksek ilişkiyi etik iklim ile demokratik yönetim arasında görmekteyiz.

Tablo 4: Korelasyon Analizi Sonuçları

\begin{tabular}{|l|l|l|l|l|l|l|l|l|l|l|}
\hline & KS & PS & ÖYS & FS & Ei & STY & OY & DY & PY & ÖS \\
\hline KS & 1 & & & & & & & & & \\
\hline PS &, $695^{* *}$ & 1 & & & & & & & & \\
\hline ÖYS &, $555^{* *}$ &, $743^{* *}$ & 1 & & & & & & & \\
\hline FS &, $549^{* *}$ &, $621^{* *}$ &, $650^{* *}$ & 1 & & & & & & \\
\hline Ei &, $221^{* *}$ &, $240^{* *}$ &, $240^{* *}$ &, $176^{* *}$ & 1 & & & & & \\
\hline STY &, $202^{* *}$ &, $246^{* *}$ &, $266^{* *}$ &, $301^{* *}$ &, $156^{* *}$ & 1 & & & & \\
\hline OY &, $377^{* *}$ &, $439^{* *}$ &, $384^{* *}$ &, $517^{* *}$ &, $264^{* *}$ &, $391^{* *}$ & 1 & & & \\
\hline DY &, $180^{* *}$ &, $148^{*}$ &, $258^{* *}$ &, $234^{* *}$ &, $380^{* *}$ &, $206^{* *}$ &, $347^{* *}$ & 1 & & \\
\hline PY &, 098 &, $170^{* *}$ &, $299^{* *}$ &, $272^{* *}$ &, $323^{* *}$ &, $284^{* *}$ &, $337^{* *}$ &, $711^{* *}$ & 1 & \\
\hline ÖS &, $831^{* *}$ &, $896^{* *}$ &, $864^{* *}$ &, $796^{* *}$ &, $253^{* *}$ &, $281^{* *}$ &, $502^{* *}$ &, $228^{* *}$ &, $230^{* *}$ & 1 \\
\hline Ort. & 3,94 & 3,92 & 4,03 & 3,35 & 4,60 & 3,36 & 3,54 & 4,27 & 3,95 & 3,84 \\
\hline Std.Sp. & 1,82 & 1,80 & 1,73 & 1,71 & 1,56 & 1,87 & 1,76 & 1,78 & 1,92 & 1,52 \\
\hline
\end{tabular}

\section{$* * \mathrm{p}<0,01, * \mathrm{p}<0,05$}

(KS: Kabullenici Sessizlik, PS: Pasif Sessizlik, ÖYS: Örgüt Yararına Sessizlik, FS: Fırsatçı Sessizlik, Ei: Etik İlim, STY: Serbestlik Tanıyan Yönetim, OY: Otoriter Yönetim, DY: Demokratik Yönetim, PY: Paternalist Yönetim, ÖS: Örgütsel Sessizlik)

Korelasyon tablosu ile elde edilen bulgular değerlendirildiğinde; kurum içerisinde demokratik ve paternalist yönetim tarzı çerçevesinde aile ortamının oluşturulması, çalışanlara eşit, saygıı davranılması ve yaratıcılıklarını göstermeleri için fırsat verilmesi durumunda kurum çalışanlarının, uyumun bozulmaması ve arkadaşlık ortamının devam etmesi için sessiz kalacaklarını söylemek mümkündür. Kurum içerisinde otoriter yönetim tarzı çerçevesinde baskılı, kuralcı ve mutlak itaat anlayışının etkin olması durumunda ise çalışanların negatif sonuçlarla karşılaşma, başkalarının avantajlı duruma geçmesi ve iş yükünün artması gibi korkulardan dolayı sessiz kalabilecekleri sonucu elde edilmiştir Alparslan'ın (2010) yaptığı 
araştırmada üst yönetimin tutumları ile çalışanların örgüt yararına sessiz kalmaları arasında anlamlı bir ilişki ortaya konulmuştur.

Kurum içerisinde demokratik yönetim tarzı çerçevesinde çalışanlara eşit ve saygılı davranılarak kararlara katılımlarının sağlanması durumunda etik dışı davranışların önlenerek etik kurallara uyulması söz konusu olabilmektedir. Kurum içerisinde etik kurallara uyulması yönünde tutum ile çabaların olması ve etik dışı davranışların cezalandırılması durumunda bu çalışma ortamının ve uyumun bozulmaması için çalışanların sessiz kalması söz konusu olabilmektedir.

\section{SONUÇ}

Yönetim tarzı, etik iklim ve örgütsel sessizlik boyut ile alt boyutlarının ilişkileri hakkında elde edilen sonuçlara bakıldığında: Yönetimin örgüt içerisinde takım ruhunu ve işbirliğini sağlayabilmek için çaba sarf etmesi durumunda; çalışanlar bu ortamın bozulmaması için fikirlerini beyan etmeyebilirler. Yönetim kademesinin çalışanlara eşit, haklarına saygılı ve yol gösterici bir şekilde davranması örgüt içerisinde iyi bir arkadaşlık ve verimlilik sağlayacağından bu ortamın bozulmaması için çalışanların sessiz kalması söz konusu olmaktadır. Yönetim kademesinin çalışanları baskı, disiplin ve itaat çerçevesinde değerlendirmesi durumunda; çalışanlar korku, yöneticilere yaranma ve kurnazlık duygusuyla sessizlik haline girebilmektedirler. Hastane içerisinde katılımcı, eşit ve demokratik bir yönetim tarzının olması durumunda; etik dışı davranışlarının kurum içerisinde söz konusu olmayacağı şeklinde bir sonuca ulaşılmaktadır. Kurum içerisinde etik kuralların olması ve yönetimin etik davranışları desteklemesi durumunda; hastane personeli bu etik ortamın bozulmaması için çalışanlar lehine sessiz kalacakları sonucu elde edilmiştir. Yapılan araştırmada yönetim tarzları, etik iklim, örgütsel sessizlik değişkenlerinin ve alt boyutlarının ikili anlamlı ilişkilere sahip olduğu anlaşılmıştır. Bu ilişkilerden yola çıkarak yönetim tarzlarının örgütsel sessizlik üzerindeki etkisinde etik iklimin moderatör rolünün araştırılması için çalışmalar yapılması önerilmektedir. Bizim çalışmamızın bu konuda bir ön ayak olacağını düşünmekteyiz. Ayrıca örneklemin genişletilerek daha geniş örneklemlere aynı araştırmanın yapılması önerilmektedir. Böylelikle bulunan sonuçların karşılaştırılması yoluna da gidilebilir. Çalışma ortamlarının sağlık şartları olarak biraz daha iyileştirilmesi veya çalışma sürelerinin olumsuz şartlardan en az etkilenecek şekilde ayarlanması önerilmektedir. Böylelikle personelin örgüt içerisindeki rahatsız oldukları durumlar ve ümitsizce sessiz kalmaları minimuma indirilmiş olur.

\section{KAYNAKLAR}

Barnett, T. ve Schubert, E. (2002). Perceptions of the ethical work climate and covenantal relationships. Journal of Business Ethics, vol. 36, no. 3, p. 279-290.

Batmaz, M. (2012). Yöneticilerin yönetim tarzlarının çalışanların iş doyumlarına etkileri. (Yayınlanmış Yüksek Lisans Tezi) Ankara: Ufuk Üniversitesi Sosyal Bilimler Enstitüsü.

Bektaş, M. (2014). Yönetim tarzlarının örgütlerdeki informal iletişim kanallarına etkisi: burdur ili kamu kurumları örneği. (Yayınlanmış Doktora Tezi). Isparta: Süleyman Demirel Üniversitesi Sosyal Bilimler Enstitüsü.

Bilgen, A. (2014). Çalışanların etik liderlik ve etik iklim algılamalarının örgütsel bağlılıklarına etkisi: özel ve kamu sektöründe karşılaştırmalı bir uygulama. (Yayınlanmış Yüksek Lisans Tezi). İstanbul: Bahçeşehir Üniversitesi Sosyal Bilimler Enstitüsü.

Brinsfield C. (2009). Employee silence: investigation of dimensionality, development of measures, and examination of related factors dissertation. (Yayımlanmamış Doktora Tezi). U.S.A.: Ohio State University.

Büte, M. (2011). Etik iklim, örgütsel güven ve bireysel performans arasındaki ilişki. Atatürk Üniversitesi İktisadi ve İdari Bilimler Dergisi, cilt. 25, sayı. 1, s. 171-192.

Çakıcı, A. (2010). Örgütlerde işgören sessizliği: neden sessiz kalmayı tercih ediyoruz? (1. Baskı). Ankara: Detay Yayıncılık.

Cengiz, S. (2010). İlköğretim okulu yöneticilerinin yönetim tarzlarının öğretmenleri yıldırma (mobbing) düzeyine etkisi. (Yayınlanmış Yüksek Lisans Tezi) Sakarya: Sakarya Üniversitesi Sosyal Bilimler Enstitüsü.

Cullen, J. B., Parboteeah, K. P. ve Victor, B. (2003). The effects of ethical climates on organizational commitment: a two-study analysis. Journal of Business Ethics, vol. 46, p. 127-141.

Dyne, L. V., Ang, S. ve Botero, I.C. (2003). Conceptualizing employee silence and employee voice as multidimensional construct. Journal of Management Studies, vol. 40, p. 1359-1392.

Erenler, E. (2010). Çalışanlarda sessizlik davranışının bazı kişisel ve örgütsel özelliklerle ilişkisi: turizm sektöründe bir alan araştırması. (Yayınlanmamış Doktora Tezi). Ankara: Hacettepe Üniversitesi Sosyal Bilimler Enstitüsü. 
Fişek, K. (2011). Yönetim (3.Baskı). Ankara: Kilit Yayınları.

Gül, H. (2006). Etik dışı davranışlar ve ulusallaştırılması: devlet hastanelerinde bir uygulama". Selçuk Üniversitesi Karaman iißBF Dergisi, cilt. 10 , no. 9, s. 65-79.

Kahya, C. (2015). Mesleki özyeterlilik ve örgütsel sessizlik ilişkisini belirlemeye yönelik ampirik bir çalışma. Çankırı Karatekin Üniversitesi İktisadi ve İdari Bilimler Fakültesi Dergisi, cilt. 5, sayı.1, s. 293-314.

Karacaoğlu, K. ve Küçükköylü, C. (2015). İşg̈ren sessizliğinin örgütsel sinizme etkisi: kamu çalışanları üzerine bir araştırma. Ege Akademik Bakış Dergisi, cilt. 15, no. 3, s. 401-408.

Knoll, K. ve Dick, R. V. (2013). Do I hear the whistle? a first attempt to measure four forms of employee silence and their correlates. Journal Bus Ethics, vol. 113, p. 349-362.

Örs, N. (2010). Örgüt kültürü tipleri ile yönetim tarzları arasındaki ilişkinin kamu örgütlerinde incelenmesine yönelik bir araştırma. (Yayınlanmış Yüksek Lisans Tezi). İstanbul: Yıldız Teknik Üniversitesi Sosyal Bilimler Enstitüsü.

Özdevecioğlu, M. (2003). Algılanan örgütsel destek ile örgütsel bağlılık arasındaki ilişkilerin belirlenmesine yönelik bir araştırma. D.E.Ü. i.i.i.B.Fergisi, cilt. 18, sayı. 2, s. 113-130.

Özgen, I., Sürgevil, O. (2009). Örgütsel sessizlik olgusu ve turizm işletmeleri açısından değerlendirilmesi. Zeyyat Sabuncuoğlu (Ed.), Turizm işletmelerinde örgütsel davranış içinde. Bursa: MKM Yayıncılık.

Parboteeah, K. P., Cullen, J. B., Victor, B. ve Sakano, T., (2005). National culture and ethical climates: a comparison of u.s. and japanese accounting firms. Management International Review, vol. 45, no. 4, p. 459-481.

Pellegrini, E. K. ve Scandura, T. A. (2008). Paternalistic leadership: a review and agenda for future research. Journal of Management, vol. 34, no. 3, p. 566-593.

Pinder, C. C. ve Harlos, K. P. (2001). Employee silence: quiescence and acquiescence as responses to perceived injustice. Research in Personnel and Human Research Management, vol. 20, p. 331-369.

Sağnak, M. (2005). Illköğretim okullarında görevli yönetici ve öğretmenlerin örgütsel etik iklim türlerine ilişkin algı ve doyum düzeyleri, Eurasian Journal of Educational Research, vol. 20, p. 203-211.

Schwepker, C. H., and David J. G. (2009). Ethical climate's influence on sales management practices. Journal of Selling \& Major Account Management. vol. 9, no. 1, p. 8-24

Şehitoğlu, Y. (2010). Örgütsel sessizlik örgütsel vatandaşlık davranışı ve algılanan çalışan performansı ilişkisi. (Yayınlanmış Doktora Tezi). Gebze: Gebze Yüksek Teknoloji Enstitüsü Sosyal Bilimler Enstitüsü.

Sonakın, C. (2010). Hemşirelerin iş doyumları ile çalıştıkları kurumların etik iklimi arasındaki ilişki. (Yayınlanmış Yüksek Lisans Tezi). İstanbul: Marmara Üniversitesi Sağlık Bilimleri Enstitüsü.

Yanık, C. (2012). Örgütsel sessizlik ile güven arasındaki ilişki ve eğitim örgütlerinde bir araştırma. (Yayınlanmış Yüksek Lisans Tezi). İstanbul: Yeditepe Üniversitesi Sosyal Bilimler Enstitüsü. 